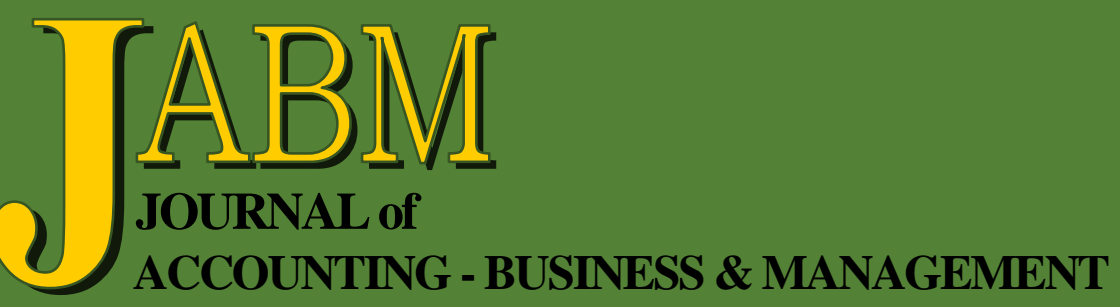

Individualism versus Collectivism Orientation as Moderator between Co-Workers' Social Support and Work to Family Enrichment

Aneel Kumar, Khalil Ahmed Channa and Muhammad Waqas Maharvi

Strategic Alliances in Knowledge-Intensive Industries: An Integrated View

Yongliang Stanley Han and Xiang Liu

Strategic Investment Decisions: An Empirical Study of Power Sector in India

Santosh Phulpagar, Koilakuntla Maddulety, Srinath Jagannathan, and Shalini Kalia

The Design of a Web-Based Program for Reporting Incomes Tax Article 21 for Civil Servants

Damayanti and Tri Sandhika Jaya

The Deceitfulness of Sticky Costs on Banking Systems

César Vela-Beltrán-del-Río and Luis Felipe Llanos Reynoso 
Journal of Accounting - Business \& Management vol. 25 no. 2 (2018) 10-21

\title{
Strategic Alliances in Knowledge-Intensive Industries: An Integrated View
}

\author{
Yongliang Stanley Han* \\ Xiang Liu ${ }^{\dagger}$
}

\begin{abstract}
In this study, we examine strategic alliances between large pharmaceutical companies (LPCs) and new biotechnology firms (NBFs) in the knowledge-intensive biopharmaceutical industry in the light of two explanations for the motives behind R\&D alliances, namely, the transaction cost explanation and the learning with flexibility explanation. We develop a series of propositions based on an integrated view of the motives behind strategic alliances in knowledge-based industries.
\end{abstract}

Keywords: strategic alliances, $\mathrm{R} \& \mathrm{D}$, transaction cost economics, learning, biotechnology.

\section{INTRODUCTION}

With the emergence of the "new biotechnology", which differs from earlier biotechnology in its focus on engineering specific changes in the genetic structure of microorganisms, over a thousand "new biotechnology firms" (NBFs) have been founded in the United States since the 1970s (Kenney, 1986; Pisano et al., 1988; Kuznetsova, 2016; and Shin et al., 2016). As drug research is switching from a chemical to a biological basis, biotechnology has been widely perceived as a destructive or "competence-destroying" innovation for the pharmaceutical industry (Tushman \& Anderson, 1986; Powell et al., 1996; Manso, 2011; Oakey, 2013; Segers, 2015; and Martynov, 2017).

Large pharmaceutical companies (LPCs) entered relatively late into the biotechnology industry. The emergence of biotechnology has changed to a great extent the way in which LPCs obtain critical R\&D capabilities. Due to the complex nature of biotechnology, knowledge transfer in biotechnology R\&D often entails severe problems such as uncertainty and weak appropriability (Pisano, 1990; Gravier et al., 2008; and Kuznetsova, 2016). Therefore, exchange of knowledge in biotechnology cannot be mediated by arm's-length market transactions. Instead, it requires stronger governance structures such as strategic alliances (e.g., R\&D contracts, R\&D collaborations, joint ventures) and vertical integration (Williamson, 1985, 1991). Before the new biotechnology was invented, LPCs had few if any strategic alliances with small R\&D firms (Pisano et al., 1988; Barley et al., 1992; Hoang \& Rothaermel, 2016; and Martins, 2016). To catch up with the new technological wave, LPCs have not only invested considerable resources in internal $\mathrm{R} \& \mathrm{D}$ projects in biotechnology, but also built various linkages with other firms and research institutions. Among all the alliance partners, NBFs were the most critical ones, due to their comparative advantage in conducting biotechnology R\&D projects (Gambardella, 1995; Manso, 2011; Oakey, 2013; Segers, 2015; and Kuznetsova, 2016).

\footnotetext{
${ }^{*}$ College of Business Administration, California State University, Sacramento. Sacramento, California 95819-6088, U.S.A. 916-278-6303.E-mail: hans@csus.edu.

† Jack H. Brown College of Business and Public Administration, California State University, San Bernardino. San Bernardino, CA 92407, USA. 909-537-5775. E-mail: xliu@csusb.edu.
} 
While there have been a number of studies of NBFs' alliance strategies (e.g., Barley et al., 1992; Kogut et al., 1992; Shan et al., 1994; Liebeskind et al., 1996; Powell et al., 1996; Baum, 2000; and Shin et al., 2016), only few studies to date have examined the alliance strategies of LPCs in biotechnology (e.g., Arora \& Gambardella, 1990; Gambardella, 1995; Gravier et al., 2008; and Martynov, 2017). In this study, we attempt to fill this gap by examining R\&D alliances established by LPCs with NBFs. We seek to interpret strategic alliances in the biopharmaceutical industry in the light of two explanations - the transaction cost explanation and the learning with flexibility explanation.

\section{LITERATURE REVIEW AND PROPOSITIONS}

\subsection{Transaction Cost Explanation}

Transaction cost economics (TCE) provides a set of coherent arguments as to when contracts will be organized within a "firm" as opposed to taking place between separate parties. According to TCE, the firm is seen as a "nexus of contracts" between a multitude of parties. The main hypothesis of TCE is that contractual designs or "governance structures" are created to minimize the sum of production costs and transaction costs between specialized factors of production (Coase, 1937; Klein et al., 1978). Williamson $(1975,1985)$ has identified uncertainty and asset specificity as two factors that play a critical role in the choice of governance structure. If transactional features do not match with governance structure, then either inefficiency or hold-up hazards will ensue. Specifically, if transactions with low level of uncertainty and asset specificity are conducted exclusively in a hierarchical organization, then the organization may not be able to achieve the same efficiency as market does due to slow external adaptation and lowered incentive. On the other hand, if transactions with high level of uncertainty and asset specificity are conducted in a governance structure without sufficient administrative controls and safeguard mechanisms, then hold-up will become a severe problem.

\subsection{Misappropriation Hazards and Governance in Biotechnology R\&D}

A second source of transaction hazards, namely, the hazard of misappropriation, has been identified by Teece (1980, 1982, and 1986). Arrow (1962) points out that knowledge is inherently a public good. In order to garner profits from knowledge, the firm must prevent its dissipation to, and its use by, its competitors. In other words, the firm's knowledge must be protected by a tight "regime of appropriability". Misappropriation hazards arise when profits generated from knowledge is improperly captured by competitors of the original owner of knowledge (Martins, 2016; Meier et al., 2016; and Martynov, 2017).

Merges et al. (1997) and Liebeskind (1999) argue that it is often difficult and costly to claim knowledge as private property per se. When knowledge transactions are concerned, ownership rights are frequently incomplete. Therefore, misappropriation hazards are caused primarily by incomplete property rights, rather than by the threat of hold-up due to asset specificity (Anton \& Yao, 1994, 1995; Meier et al., 2016; and Shin et al., 2016). Moreover, even if legally enforceable property rights in knowledge can be established, enforcement still entails high costs, which is due to the "natural nonexcludability" of knowledge. Incomplete contracting in knowledge transactions imposes a threat to the owner of knowledge to perfectly appropriate benefits from its use. As a response, the firm may consider internalization of these transactions to resolve this problem (Von Hippel, 1982; Gravier et al., 2008; and Kuznetsova, 2016). First, 
combined ownership rights can moderate incentives for misappropriation (Grossman \& Hart, 1986; Hart \& Moore, 1990). Second, the selective intervention of management in a firm can resolve disputes over division of surplus at lower cost than involvement of the courts (Coase, 1937; Williamson, 1975).

In biotechnology $\mathrm{R} \& \mathrm{D}$, with the recent scientific developments in molecular biology and genetic engineering, drug innovations depend more upon knowledge and information that are "generic" in nature, and that can be transferred at low cost among different agents (Gambardella, 1995). As a result, asset specificity has been considerably reduced in this new field of pharmaceutical $R \& D$. While asset specificity has been moderated, technological uncertainty and the resulting weak appropriability regime remain persistent problems in biotechnology $R \& D$, especially when transfer of knowledge and specification of property rights are concerned. Gambardella (1995) argues that most R\&D activities in the biopharmaceutical industry cannot be mediated by arm's length market transactions due to high uncertainty and severe misappropriation hazards. Therefore, broadly speaking, internal development and strategic alliances are the only two viable organizational options in these settings (Martins, 2016; Martynov, 2017). Moreover, Pisano (1990) points out that in biotechnology $\mathrm{R} \& \mathrm{D}$, technological uncertainties are often intertwined with contractual uncertainties. Specifically, when an R\&D project is conducted in-house, the R\&D team can be prohibited by fiat from leaking know-how to competitors. When the project is done externally, however, restrictions on transferring know-how must be incorporated into the contractual agreement and then strictly enforced, which may be both difficult and costly. Pisano (1990) thus argues that the hazards of repeatedly entering into contractual agreements that involve misappropriation hazards provide an incentive for vertical integration. In line with these TCE-based arguments, we propose the following:

Proposition 1: Given the high uncertainty and severe misappropriation hazards associated with ReDD projects in biotechnology, LPCs will strictly prefer internalization of biotechnology $R \& D$ to $R \& D$ alliances.

\subsection{Industrial Reality and Critiques of TCE}

One critique of TCE centers on the assumed substitutability between internal development and strategic alliances in R\&D. TCE argues that to optimally organize its R\&D activities, a firm's choice between internal development and strategic alliances is primarily driven by governance efficiency considerations. An implicit assumption underlying this choice is that $\mathrm{R} \& \mathrm{D}$ capabilities in internal organization and strategic alliances are equally available. Therefore, different organization modes are substitutable in terms of their access to technological capabilities.

However, the "substitution hypothesis" is arguably based on an erroneous interpretation of industrial realities (Foray, 1991). Gambardella (1995) and Powell (1996) argue that biotechnology represents a competence-destroying innovation because it builds on a scientific basis (e.g., immunology and molecular biology) that fundamentally differs from the knowledge base of the traditional pharmaceutical industry (e.g., organic chemistry). Gambardella (1995) predicts that there will be a persistent knowledge-based division of labor in the biotechnology field: the industry will be composed of a large number of small, flexibly organized, research-intensive companies (i.e., NBFs), with comparative advantages in producing ideas, and a few large established firms with comparative advantages in large-scale development and commercialization. This prediction has been widely confirmed: there has been a recent spate of mergers among LPCs, while NBFs continue to be founded and existing NBFs 
continue to persist as free-standing firms. Apparently, most NBFs have persisted and thrived because they have unique $R \& D$ capabilities. These capabilities are not owned but are highly valued by large established pharmaceutical companies that consequently form numerous R\&D alliances with NBFs. In other words, there cannot be substitutability in biotechnology R\&D: certain resources or R\&D capabilities cannot be acquired through internal development, due to technological or economic reasons. We term this phenomenon "barriers to internalization".

Henderson and Clark (1990) and Henderson (1993) push the non-substitutability argument further by proposing that when radical innovations (e.g., biotechnology) appear, organizational rigidity and inertia hinder the ability of established firms (e.g., LPCs) to take advantage of the new opportunities. New entrants, or newly established firms (e.g., NBFs), with no sunk costs and organizational biases towards the old technology, can be far more effective than incumbents in exploiting the new fields. This theory can explain the fact that large established chemical and pharmaceutical companies entered relatively late into biotechnology.

While Henderson and Clark (1990) and Henderson (1993) challenge the substitutability argument primarily from a technological perspective, Argyres and Liebeskind $(1999,2002)$ provide a governance explanation for the persistent division of labor in the biotechnology industry. They argue that in the early years of the biotechnology industry, large incumbent firms (i.e., LPCs) were unable to offer the kinds of organizational arrangements (e.g., incentive mechanisms) that small firms could offer to attract, retain, and motivate biotechnology scientists. These constraints were obtained because large incumbent firms' prior governance choices reduced the range of their governance choices for subsequent and different types of transactions (i.e., biotechnology $\mathrm{R} \& \mathrm{D}$ projects). As a result, large incumbent firms had a comparative disadvantage over NBFs in many areas of biotechnology because NBFs had the governance structure that was more conducive to $\mathrm{R} \& \mathrm{D}$ activities. This argument receives support from Pisano et al. (1988).

In sum, when an LPC faces significant barriers to internalization, it has to turn to $\mathrm{NBF}$ to obtain key technologies in certain therapeutic or diagnostic areas (Di Guardo \& Harrigan, 2016; Martins, 2016; and Martynov, 2017). Under these circumstances, however, transaction hazards may not only persist, but also worsen, because of NBFs' bargaining power due to their monopoly in biotechnology know-how. According to the TCE logic, to avoid these hazards of both misappropriation and bargaining power, as an LPC accumulates more and more internal R\&D capabilities in biotechnology, it will internalize $\mathrm{R} \& \mathrm{D}$ projects rather than conduct $\mathrm{R} \& \mathrm{D}$ through alliances. Hence:

Proposition 2: As LPCs' internal R \&D capabilities in biotechnology increase, their rate of forming R\&D alliances with $N B F$ s will decrease.

\subsection{Governance of Strategic Alliances and Use of Equity}

Given that barriers to internalization may prevent LPCs from fully internalizing essential new capabilities, the question arises as to how they might arrange to access those capabilities through alliances and how these alliances may be governed. Oxley (1997) examines the effect of misappropriation hazards on a firm's choice among governance modes in technology transfer alliances. She predicts that when property rights associated with the technology are difficult to define in the contract and when the scope of R\&D activities is broader, so that the monitoring of these activities is hampered, partner firms may prefer more "hierarchical" alliances (e.g., joint ventures) in order to maintain tight control and to reduce misappropriation hazards. In contrast, 
when property rights are easier to specify in the contract and when the scope of R\&D activities is narrower, partner firms may choose more "market-like" governance structure in technology alliances (e.g., a license agreement). Oxley's empirical results provide strong support to her arguments.

When significant barriers to internalization exist for technological or organizational reasons, firms are likely to use equity investment to facilitate and protect their cooperative activities, since a greater degree of ownership can provide tighter administrative control for dealing with potentially opportunistic partners (Williamson, 1985). The use of equity in strategic alliances has been widely recognized as a safeguard mechanism against misappropriation hazards, especially when alliance partners are faced with uncertainty and asset specificity. For instance, Grossman and Hart (1986) argue that equity ownership defines the default options in an incomplete contract and can better align the partner firms' incentives.

A closer look at R\&D alliances in biotechnology reveals a mutual hold-up problem. While NBFs have an advantage in upstream R\&D capabilities in biotechnology, LPCs own critical complementary assets and skills in downstream manufacturing and marketing (Teece, 1986; Pisano et al., 1988; Sosa, 2009; and Martins, 2016). Once an LPC and an NBF enter into an R\&D alliance, they become dependent on each other. Under these circumstances, transaction cost economists suggest that we should observe more "hierarchical" forms of R\&D alliances in biotechnology. Since equity provides an effective means to address agency or misappropriation concerns, it is logical to use equity investment to maintain hierarchical controls in R\&D alliances in biotechnology (Gulati \& Singh, 1998; Oakey, 2013; Segers, 2015; Martins, 2016; and Meier et al., 2016). Hence:

\section{Proposition 3: A large proportion of R\&D alliances between LPCs and} NBFs will be in the form of either minority-equity-based R\&D projects or joint ventures.

\subsection{The Learning with Flexibility Explanation}

Learning from internal and external sources has been viewed as one of the most prominent competencies for firms competing in knowledge-intensive industries. Learning can explain both a firm's competitive advantage and its scope. Mody (1993) and Veltri et al., (2015) argue that learning is a strong motive for forming and sustaining alliances. Other authors, including Powell and Brantley (1992), Khanna (1996), and Wuyts and Dutta (2014) also suggest that one of the strongest motives for collaboration is the acquisition of new technical skills or technological capabilities from partner firms.

Powell et al. (1996) and Wuyts and Dutta (2014) argue that since the knowledge base in many high-tech industries is both sophisticated and expanding, and since the sources of expertise are widely dispersed, the locus of innovation will be found in "networks of learning", rather than in individual firms. Therefore the complex reality of rapidly developing fields transcends the simple calculation of a make-or-buy decision, as proposed by transaction cost economists. Rather, an established firm's top priority is accessing new technology and resolving technological uncertainty. Referring to the biotechnology field, Kenney (1986) argues that a research contract with or without an equity component can be used by an LPC to secure "a window of technology" at relatively low cost. In many research contracts the LPC is investing money merely to discover the potential of biotechnology. For the LPC this probationary investment will lead to a corporate decision to either seek greater involvement or to abandon any further efforts to enter the field. Many LPCs demand 
a seat on the NBF's board of directors as a condition for making a major equity investment. This allows the LPCs not only to insure their investment but also to discover what opportunities they feel are worth pursuing.

\subsection{Learning with Flexibility versus Resource Commitment}

Mody (1993), Xu et al., (2014) and Di Guardo and Harrigan (2016) propose that alliances have the advantage of preserving flexibility in the face of uncertainty, while internalization requires substantial commitment and leads to a rigid structure. Internalization, moreover, is unlikely to occur when information and technological expertise have to be acquired from a variety of sources.

TCE rarely considers the issue of resource constraints. As we have discussed in the previous section, TCE assumes universal availability of resources and that the efficiencies of deploying resources inside and outside an organization (hierarchy) are equivalent. However, integration of a resource can have long-term effects on an organization other than reducing transaction costs. For instance, Foray (1991) points out that integration enables a firm to increase its commitment to technology-creating processes. Numerous works show that internalizing a resource tends to make this resource more and more specific as the organization develops in time and as the resource becomes more specific to other internal resources (Penrose, 1959; Nonaka, 1994; Pangarkar \& Wu, 2013; and Xu et al., 2014). Consequently, the integrated resource will qualitatively change the organization, especially by improving its learning capacity. In a similar vein, Poppo and Zenger (1998) argue that hierarchies are largely unstoppable engines of cospecialization yielding increasingly firm-specific language and routines. However, integration also substantially reduces the organization's freedom to redeploy resources to possibly more productive uses in the future. Moreover, Poppo and Zenger (1998) argue that to the extent that cospecialization generates language and routines that prevent the acquisition of new knowledge sources, internalizing activities can destroy value for the firm. One of the reasons is that it is difficult and costly to change elements of a large, integrated system of co-specific resources and capabilities. Hence, internalization engenders "technological irreversibility" (Foray, 1991; Veltri et al., 2015; and Di Guardo \& Harrigan, 2016). While associating co-specific resources within an organization in the process of technology creation is critical to avoiding hold up (Klein et al., 1978), internalization entails the risk of incurring irreversibility costs.

The trade-off between resource commitment and preserving organizational flexibility can be observed in various industries. Mitchell and Singh (1992) argue that industry incumbents frequently delay entry into emerging technical subfields to avoid product cannibalization and uncertain investment; they enter only after technical and market uncertainties have subsided. Using evidence from the medical diagnostic imaging industry, they find that many incumbents participate in alliances with other firms before their standalone entry. Similarly, Folta (1998) suggests that while equity collaborations may sacrifice administrative control relative to acquisition or in-house development, such collaborations also provide a way to economize on the costs of committing to a technology with an uncertain future value.

In the context of the biotechnology industry, the costs of irreversibility can be understood as opportunity costs. If an LPC commits a large portion of its resources to a relatively small number of internal $\mathrm{R} \& \mathrm{D}$ projects, it may incur the opportunity costs of missing other promising $\mathrm{R} \& \mathrm{D}$ projects in which it could participate via alliance. Hence, the firm may prefer to deploy its scarce financial and human resources in 
a number of R\&D alliances to monitor new technological opportunities and to preserve organizational flexibility. Hence:

Proposition 4: LPCs will prefer R\&D alliances with NBFs to internalization to maintain organizational flexibility in biotechnology R $\mho D$.

The question remains, however, about how such alliances will be organized. While equity-based alliances give firms tighter administrative control over R\&D projects (Oxley, 1997; Sosa, 2009; Manso, 2011; Xu et al., 2014; and Hoang \& Rothaermel, 2016), they will inevitably consume more financial and organizational resources and arguably incur more irreversibilities than less "hierarchical" alliances such as R\&D contracts. Veltri et al. (2015) argue that in the initial stages of the technological trajectories of a new technological paradigm, or R\&D activities aimed at exploring the opportunities offered by a radically new technology, uncertainty is so overwhelmingly high that effectiveness in monitoring partner's behavior is rather insensitive to the chosen governance mode. As a result, firms may choose to use more flexible contractual arrangements as opposed to making costly (and to some extent unrecoverable) equity investments in $\mathrm{R} \& \mathrm{D}$ alliances. Due to high technological uncertainty inherent in biotechnology R\&D alliances, it can be expected that LPCs will prefer contractual arrangements to equity-based alliances, due to the need for preserving strategic flexibility. Hence:

Proposition 5: LPCs will prefer non-equity-based R\&D alliances to equity alliances with NBFs to maintain organizational flexibility.

\subsection{Co-Evolution of Internal R\&D Capabilities and R\&D Alliances}

Contrary to TCE's traditional substitutability proposition, Arora and Gambardella (1990) argue that knowledge creation through internal development and knowledge acquisitions through external organization modes are not mutually exclusive; instead, they are complementary. Similarly, through their observation of technological cooperation in biotechnology, Powell et al. (1996) conclude that internal capabilities and external collaboration are not substitutes for one another, but complementary. A firm with greater capacity to learn is adept at both internal and external R\&D, which enables it to contribute more to collaboration as well as learn more extensively from its partner. Pisano et al. (1988) and Hutzschenreuter and Horstkotte (2010) also suggest that firms with stronger in-house capabilities are better able to identify, absorb, and apply the valuable technology from external sources, since the multidisciplinary nature of biotechnology and the breadth of its potential application make it very difficult for any firm to track all of the relevant technological frontiers through in-house R\&D (Pangarkar \& Wu, 2013; Hoang \& Rothaermel, 2016).

The above arguments are consistent with the concept of "absorptive capacity" proposed by Cohen and Levinthal (1990). In their view, a necessary condition for a firm's successful exploitation of technological capabilities or knowledge outside its boundaries is development within the firm of the ability to absorb such capabilities. This absorptive capacity requires that a firm have considerable in-house expertise that complements the technology activities of its alliance partners. In the biotechnology industry, where knowledge is both complex and widely dispersed, in-house scientific and technological capabilities are critical for monitoring and utilizing external knowledge (Hutzschenreuter \& Horstkotte, 2010; Pangarkar \& Wu, 2013; and Veltri et al., 2015). Therefore LPCs' reliance upon external knowledge implies that they will invest substantially in internal biotechnology $\mathrm{R} \& \mathrm{D}$ as a means of monitoring external 
scientific advances. Hence, we can expect to observe a positive relationship between an LPC's R\&D investment in biotechnology R\&D and its propensity to ally with NBFs.

Absorptive capacity serves not only as a catalyst for R\&D alliances between LPCs and NBFs, but also as one of the primary governance mechanisms for those alliances. In the biotechnology industry where innovations are often radical or competence-destroying, uncertainty may become so high that the effectiveness of monitoring a partner's behavior is relatively insensitive to the formal governance mode (e.g., equity ownership). In such settings, LPCs may then rely heavily on their absorptive capacity to design contractual terms and monitor their partners' behavior. That is, their technological knowledge will be more important in reducing misappropriation hazards, than governance mode per se. In particular, LPCs' exposure to transaction hazards will decline as their knowledge about biotechnology increases. Hence:

Proposition 6: LPCs' propensity to form R\&D alliances with NBFs will increase as their internal R\&D capabilities in biotechnology increase.

\section{CONCLUDING REMARKS}

This study is subject to several limitations. In addition, many important theoretical issues remain under-explored. The first caveat concerns the compatibility and complementarity among the two explanations for the motives of R\&D alliances. It should be noted that these two explanations are not always competing; they can be compatible or complementary under some circumstances. For instance, even if an R\&D alliance is aimed at learning, the sponsoring LPC might still be interested in minimizing transaction costs by choosing the most appropriate governance mechanisms (e.g., equity investment vs. non-equity investment). Another possible scenario is that an LPC may first form learning-driven non-equity $R \& D$ alliances with several NBFs to monitor their technological advances. Once the LPC finds that an NBF is developing promising technologies that will be critical for improving its competitive position, it may then invest equity in that $\mathrm{NBF}$ to tighten administrative control over the alliances and potentially block competitors' access to the same technologies. Under these circumstances, we might find that an $\mathrm{R} \& \mathrm{D}$ alliance is actually driven by multiple motives, although these motives could impact the alliance formation process differently in terms of importance. Future research on the motives for R\&D alliances should specifically examine the compatibility and complementarity among these explanations.

The second issue concerns the possibility of examining the motives for R\&D alliances in the biotechnology industry from different perspectives. This study uses LPCs as focal firms. As a result, NBFs are treated as passive targets with which LPCs formed $\mathrm{R} \& \mathrm{D}$ alliances. However, previous studies on strategic alliances in the biotechnology industry have revealed that NBFs might enter into alliances with LPCs and other organizations (e.g., universities, research institutions, and other NBFs) for reasons that are very different from those of LPCs. For instance, a common reason for NBFs to form R\&D alliances with LPCs is to seek capital, as most NBFs are financially distressed (Kenney, 1986; Pisano et al., 1988; and Lerner, 1998). Another common reason of NBFs' involvement in R\&D alliances is to seek complementary assets and capabilities from LPCs, as LPCs control the downstream manufacturing and marketing resources and capabilities, and are more experienced in clinical trials and regulatory approval procedures than most NBFs. Therefore, future research should examine the motives behind $R \& D$ alliances in the biotechnology industry from the standpoints of both LPCs and NBFs, and the interplay of these different motives. 
Such research will greatly deepen our understanding of the formation and evolution of $\mathrm{R} \& \mathrm{D}$ alliances on the one hand, and the structure and dynamics of the biotechnology industry on the other hand.

\section{REFERENCES}

Anton, J. J, \& Yao, D. A. (1995). Start-ups, spin-offs, and internal projects. Journal of Law, Economics, \& Organization, 11(2), 362-78.

Anton, J. J., \& Yao, D. A. (1994). Expropriation and inventions: Appropriable rents in the absence of property rights. American Economic Review, 84(1), 190-209.

Argyres, N. S., \& Liebeskind, J. P. (1999). Contractual commitments, bargaining power, and governance inseparability: Incorporating history into transaction cost theory. Academy of Management Review, 24(1), 49-63.

Argyres, N. S., \& Liebeskind, J. P. (2002). Governance inseparability and the evolution of US biotechnology industry. Journal of Economic Behavior \& Organization, 47(2), 197-219.

Arora, A., \& Gambardella, A. (1990). Complementarity and external linkages: The strategies of the large firms in biotechnology. Journal of Industrial Economics, 38(4), 361-379.

Arrow, K. (1962). Economic welfare and the allocation of resources for invention. In The rate and direction of inventive activity. Princeton, New Jersey: Princeton University Press.

Barley, S. R., Freeman, J., \& Hybels, R. C. (1992). Strategic alliances in commercial biotechnology. In N. Nohria \& R. Eccles (Eds.) Networks and Organizations: Structure, Form and Action (p. 311-347). Boston, MA: Harvard Business School Press.

Baum, J. (2000). Don't go it alone: Alliance network composition and startups performance in Canadian biotechnology. Strategic Management Journal, 21(3), 267294.

Coase, R. (1937). The nature of the firm. Economica, 4(16), 386-405.

Cohen, W. M., \& Levinthal, D. A. (1990). Absorptive capacity: A new perspective on learning and innovation. Administrative Science Quarterly, 35(1), 128-152.

Di Guardo, M. C., \& Harrigan, K. R. (2016). Shaping the path to inventive activity: The role of past experience in R\&D alliances. Journal of Technology Transfer, 41(2), 250269.

Folta, T. B. (1998). Governance and uncertainty: The tradeoff between administrative control and commitment. Strategic Management Journal, 19(11), 1007-1028.

Foray, D. (1991). The secrets of industry are in the air: Industrial cooperation and the organizational dynamics of the innovative firm. Research Policy, 20(5), 393-405.

Gambardella, A. (1995). Science and innovation: The US pharmacentical industry during the 1980s. New York: Cambridge University Press.

Gravier, M. J., Strutton, D., \& Randall, W. S. (2008). Investigating the role of knowledge in alliance performance. Journal of Knowledge Management, 12(4), 117130.

Grossman, S., \& Hart, O. (1986). The costs and benefits of ownership: A theoretical of vertical and lateral integration. Journal of Political Economy, 94(4), 691-719.

Gulati, R., \& Singh, H. (1998). The architecture of cooperation: Managing coordination costs and appropriation concerns in strategic alliances. Administrative Science Quarterly, 43(4), 781-814. 
Hart, O., \& Moore, J. (1990). Property rights and the nature of the firm. Journal of Political Economy, 98(6), 1119-1158.

Henderson, R. M. (1993). Underinvestment and incompetence as responses to radical innovation: Evidence from the photolithographic alignment equipment industry. RAND Journal of Economics, 24(2), 248-270.

Henderson, R. M., \& Clark, K. B. (1990). Architectural innovation: The reconfiguration of existing product technologies and the failure of established firms. Administrative Science Quarterly, 35(1), 9-30.

Hoang, H., \& Rothaermel, F. T. (2016). How to manage alliances strategically. MIT Sloan Management Review, 58(1), 69-76.

Hutzschenreuter, T., \& Horstkotte, J. (2010). Knowledge transfer to partners: A firm level perspective. Journal of Knowledge Management, 14(3), 428-448.

Kenney, M. (1986). Biotechnology: The university-industrial complex. New Haven: Yale University Press.

Khanna, T. (1996, January). Winner-take-all alliances. Harvard Business School Working Paper, No. 96-033.

Klein, B., Crawford, R. G., \& Alchian, A. A. (1978). Vertical integration, appropriable rents and the competitive contracting process. Journal of Law \& Economics, 21(2), 281-96.

Kogut, B., Shan W., \& Walker, G. (1992). Competitive cooperation in biotechnology: Learning through networks? In N. Nohria \& R. Eccles (Eds.). Networks and organizations: Structure, form and action (p. 348-365). Boston: Harvard Business School Press.

Kuznetsova, N. V. (2016). Strategic alliances: Industry-specific characteristics of the achievement of a competitive advantage. International Journal of Economics \& Financial Issues, 6(1), 109-117.

Lerner, J. (1998) The control of technology alliances: An empirical analysis of the biotechnology industry. The Journal of Industrial Economics, 46(2), 125-156.

Liebeskind, J. (1999). Ownership, governance and incentives in new biotechnology firms. In M. Blair \& T. Kochan (Eds.). The new relationship: Human capital in the American Corporation. Cambridge, MA: MIT Press.

Liebeskind, J., Oliver, A., Zucker, L., \& Brewer, M. (1996). Social networks, learning and flexibility: Sourcing scientific knowledge in new biotechnology firms. Organization Science, 7(4), 428-43.

Manso, G. (2011). Motivating innovation. The Journal of Finance, 66(5), 1823-1860.

Martins, J. T. (2016). Relational capabilities to leverage new knowledge. The Learning Organization, 23(6), 398-414.

Martynov, A. (2017). Alliance portfolios and firm performance: The moderating role of firms' strategic positioning. Journal of Strategy \& Management, 10(2), 206-226.

Meier, M., Lütkewitte, M., Mellewigt, T., \& Decker, C. (2016). How managers can build trust in strategic alliances: A meta-analysis on the central trust-building mechanisms. Journal of Business Economics, 86(3), 229-257.

Merges, R., Menell, P. S., Lemley, M. A., \& Jorde, T. M. (1997). Intellectual property in the new technological age. New York: Aspen Publishers.

Mitchell, W., \& Singh, K. (1992). Incumbents' use of pre-entry alliances before expansion into new technical subfields of an industry. Journal of Economic Behavior \& Organization, 18(3), 347-372.

Mody, A. (1993). Learning through alliances. Journal of Economic Behavior \& Organization, 20(2), 151-170. 
Nonaka, I. (1994). A Dynamic theory of organizational knowledge creation. Organization Science, 5(1), 14-37.

Oakey, R. P. (2013). Open innovation and its relevance to industrial research and development: The case of high technology small firms. International Small Business Journal, 31(3), 319-336.

Oxley, J. E. (1997). Appropriability hazards and governance in strategic alliances: A transaction cost approach. Journal of Law, Economics, \& Organization, 13(2), 387409.

Pangarkar, N., \& Wu, J. (2013). Alliance formation, partner diversity, and performance of Singapore startups. Asia Pacific Journal of Management, 30(3), 791-807.

Penrose, E. T. (1959). The theory of the growth of the firm. Oxford: Basil Blackwell.

Pisano, G. P. (1990). The R\&D boundaries of the firm: An empirical analysis. Administrative Science Quarterly, 35(1), 153-176.

Pisano, G., Shan, W., \& Teece, D. (1988). Joint ventures and collaborations in the biotechnology industry. In D. C. Mowery (ed.). International collaborative ventures in the U.S. manufacturing (p. 183-222). Cambridge, MA: Ballinger.

Poppo, L., \& Zenger, T. (1998). Testing alternative theories of the firm: Transaction cost, knowledge-based, and measurement explanations for make-or-buy decisions in information services. Strategic Management Journal, 19(9), 853-877.

Powell, W. W. (1996). Inter-organizational collaboration in the biotechnology industry. Journal of Institutional \& Theoretical Economics, 152(1), 197-215.

Powell, W. W., Koput, K. W., \& Smith-Doerr, L. (1996). Interorganizational collaboration and the locus of innovation: Networks of learning in biotechnology. Administrative Science Quarterly, 41(1), 116-145.

Powell, W., \& Brantley, P. (1992). Competitive cooperation in biotechnology: Learning through networks? In N. Nohria \& R. Eccles (Eds.) Networks and Organizations: Structure, Form and Action (p. 365-394). Boston, MA: Harvard Business School Press.

Segers, J. P. (2015). The interplay between new technology based firms, strategic alliances and open innovation, within a regional systems of innovation context. The case of the biotechnology cluster in Belgium. Journal of Global Entrepreneurship Research, 5(16), 1-17.

Shan, W., Walker, G., \& Kogut, B. (1994). Interfirm cooperation and startup innovation in the biotechnology industry. Strategic Management Journal, 15(5), 387394.

Shin, K., Kim, S. J., \& Park, G. (2016). How does the partner type in R\&D alliances impact technological innovation performance? A study on the Korean biotechnology industry. Asia Pacific Journal of Management, 33(1), 141-164.

Teece, D. J. (1980). Economies of scope and the scope of the enterprise. Journal of Economic Behavior \& Organization, 1(3), 223-45.

Teece, D. J. (1982). Towards an economic theory of the multiproduct firm. Journal of Economic Behavior \& Organization, 3(1), 39-64.

Teece, D. J. (1986). Profiting from technological innovation: Implications for integration, collaboration, licensing, and public policy. Research Policy, 15(6), 285305.

Tushman, M., \& Anderson, P. (1986). Technological discontinuities and organizational environments. Administrative Science Quarterly, 31(3), 439-465.

Veltri, S., Venturelli, A., \& Mastroleo, G. (2015). Measuring intellectual capital in a firm belonging to a strategic alliance. Journal of Intellectual Capital, 16(1), 174-198. 
Von Hippel, E. (1982). Appropriability of innovation benefit as a predictor of the source of innovation. Research Policy, 11(2), 95-115.

Williamson, O. E. (1975). Markets and hierarchies: Analysis and antitrust implications. New York: Free Press.

Williamson, O. E. (1985). The economic institutions of capitalism. New York: Free Press.

Williamson, O. E. (1991, Juny). Comparative economic organization: The analysis of discrete structural alternatives. Administrative Science Quarterly, 36(2), 269-96.

Wuyts, S., \& Dutta, S. (2014). Benefiting from alliance portfolio diversity: The role of past internal knowledge creation strategy. Journal of Management, 40(6), 1653-1674.

Xu, S., Fenik, A. P., \& Shaner, M. B. (2014). Multilateral alliances and innovation output: The importance of equity and technological scope. Journal of Business Research, 67(11), 2403-2410. 